ORIGINAL PAPER

\title{
Litigious Side of the Medical Malpractice in Romania
}

\author{
Radu Mihai DUMITRESCUำ
}

\begin{abstract}
The medical malpractice has begun to come into view as a concerning reality in our health system. The reactions from mass media or at the level of various professional organizations are more and more frequent. A systematic analysis of the phenomenon is far to be completed and it would be essential for the enunciation of some adequate public policies and for some opportune legislative modifications. The clear theoretical directions are difficult to be identified such that the testing of the most representative ones is a starting point. In this article we have also made an overview of the main theoretical points. By this research a retrospective study for the period $2007-2018$ of the files concerning the medical malpractice registered at the courts of Romania has been done. I have performed an analysis of the geographical distribution of cases, the quantification of some elements as well the judicial juration and the number of involved processual parties and also the testing of some correlations with various social and economic indicators. The theory of the hazard which has its origin in the Bayes theorem does not explain fully the evolution of the phenomenon while the theory of the social control (Donald Black) explains a series of matters.
\end{abstract}

Keywords: medical malpractice, geographical distribution, litigious duration, number of processual parties, social indicators.

\section{Rezumat}

Fenomenul malpraxis-ului medical a început să se contureze ca o realitate îngrijorătoare și în cazul sistemului nostru de sănătate. Reacții în presă sau la nivelul diverselor organizații profesionale sunt din ce în ce mai frecvente. O analiză sistematică a fenomenului este însă departe de a fi finalizată și ar fi esențială pentru formularea unor politici publice adecvate cât și pentru modificări legislative oportune. Direcții teoretice clare sunt dificil de identificat așa încât testarea celor mai reprezentative reprezintă un punct de început. În acest articol am realizat și o trecere în revistă a principalelor repere teoretice. Prin cercetarea de față s-a realizat un studiu retrospectiv pentru perioada 2007-2018 al dosarelor cu privire la malpraxis-ul medical înregistrate la instanțele din România. Am realizat o analiză a repartiției geografice a cazurilor, cuantificarea unor elemente precum durata judiciară și numărul de părți procesuale implicate dar și testarea unor corelații cu diverși indicatori sociali și economici. Teoria hazardului care își are originea în teorema lui Bayes nu explică în totalitate evoluția fenomenului în timp ce teoria controlului social (Donald Black) vine să explice o serie de aspecte.

Cuvinte cheie: malpraxis medical, distribuție geografică, durată litigioasă, numărul părților procesuale, indicatori sociali.

${ }^{1}$ Doctoral School of Sociology, Bucharest University, Romania

\section{Corresponding author.}

Radu Mihai DUMITRESCU, Medicover Hospital, 8 Pechea Street,

$1^{\text {st }}$ District, Bucharest, Romania.

E-mail: dum_mihu@yahoo.com 


\section{INTRODUCTION}

The identification of some general theories which can explain the occurrence of some litigations which have as cause the medical errors or negligence and which can be used in the appreciation risk is difficult. The explanation can be found just in the fact that we talk about a multifactorial process in which various social matters interpenetrate. The connection between the medical and legal practice by which the fundamental social values (life and health) are in the center of the medical practice and in the center of the social control exercised by the law is obvious. The laws which impose a control of the medical occupation try to balance the relationship of power in the physician - patient binomial, and the civil laws, with a more general feature, impose a fundamental right: the damage brought to a person must be repaired. Various social and economic factors model the occurrence of the malpractice phenomenon in various societies; special matters of cultural level and some influenced by the media and the new information technologies produce important variations at individual and population level.

The medical literature and the one belonging to other disciplines lead us to two main directions: a theory which occurs from the sphere of mathematical probabilities and one which occurs from the sociology of law and centers on the social control exercised by the laws specific to the general civil and medical occupations.

Vasile Astărăstoaie, $\mathrm{PhD}$ and Professor, former President of the Romanian College of Physicians during 2007-2016, has emphasized the influence of hazard concerning the occurrence of medical errors. His interventions have taken place in the professional organization and in media. The analysis of the phenomenon from this perspective are practically inexistent in the autochthonous literature, but the approach can be essential for the understanding of malpractice. „Concerning the malpractice, the Schweitzer theory has been issued, following which the malpractice occurs when, due to hazard, a series of minor errors align as the holes from a cheese and create a path by which a needle can pass. And then, to diminish or even remove the malpractice, we have to analyze the system and the system must have protection and safety barriers" ${ }^{1}$.

The defenses, barriers and protection measures occupy a key position in the system functioning. The high technology systems have many defensive layers: some of the mare designed (alarms, physical barriers, automatic stops, etc.), other are based on humans (sur- geons, anesthetists, other professional people, etc.) and other depend on administrative procedures and controls as the protocols and guides of good practice. Their function is to protect the potential victims and to limit the occurrence of unwanted events. Many times, the system is an efficient one from the perspective of errors avoidance, but weak points always exist. In an ideal world, each of the defensive layer would be intact. Actually, many such slices of slices exist, having more holes which open and close permanently. The system of medical care is as complex, as fluid. The presence of holes in any slice does not produce, normally, a bad result. Usually, this can happen only when the holes from many layer align for a moment to allow a trajectory of the occasional accident - bringing dangers in the fatal contact with the victims ${ }^{2}$.

An entire series of opinions concerning the malpractice phenomenon within the context of the Romanian society can be the subject of some individual researches. If its predominance varies between the unforeseeable and hazard, it can be calculated using the Bayes theorem, knowing a series of parameters as the frequency of errors, the risk of occurrence of accidents and incidents or various pathologies and also the understanding of security mechanisms existing at level of system or individual practice. If we report to the volume of services and therapeutic interventions, probably the intensity of phenomenon is smaller and if we report to the reactions from the written or online media, we can talk about a real systemic problem. Because no believable statistic data and official reporting systems are available, we are on a subjective area which is hard to be quantified. The public opinion exercises a significant pressure by the media or anytime an intense mediated case occurs; this tendency can have as explanation the level of expectations concerning the therapeutic action being seen as infallible and the only determiner of the result. The hazard seems not to play any role in the public discourse and the next objective is the identification of the guilty person and of the deficiencies concerning the care. The local cultural matters seem to influence strongly the phenomenon existing opinions which contour our population as a "litigant" one. The Romanians' drive for trials is recognized as increased; analyzing the data of the National Statistics Institute available online (http://www.statistici.insse.ro:8077/ tempo-online/\#/pages/tables/insse-table) an increase of the number of cases submitted annually in court can be seen from 1.48 million in 2010 to 2.203 million in 2017. The articles from mass media which take data 
of the European Commission confirm that Romania is, at least in 2014, on the first place at the number of trials report to 100 inhabitants. The number is 7 and it increases against 2013 when the value has been a few over 43 . Opinions and public realities as the trust in justice and the duration for resolution bring probably important influences concerning the malpractice as phenomenon related to the action of justice. Between the reality of the fact that no medical action exists without risks and the assumed acceptance of the calculated and opportune ones, a considerable distance can exist at level of individual perception. Even though incidents can occur, which are not imposable directly to the action or medical staff, but to the hazard, it is possible that the public reaction omits this matter and, as tendency, we continue to find guilty persons. An entire series of cultural, social, economic and organizational factors of the autochthonous health system make that the theory which has as basis the hazard can only explain partially the malpractice phenomenon, even though the theory can be found in the medical literature. It is possible that the hazard explains a basic level of the phenomenon under which its predominance cannot be reduced whether of the implemented safety measures.

We talk a lot in medicine about what probability means. According to the Bayer theorem, the probability that the starting element represents the reality depends on the predominance of disease, the so-called „basic rate”. It is well-known and documented repeatedly in the literature that even the tests of sensitivities and extremely high specificities are accompanied by false positive results when the probability of pretesting is low. A common example is the measurement of heart troponin for the heart pain assessment. The troponin $\mathrm{T}$ is an extremely sensitive marker and specific for the myocardial ischemia and it is a routine test in the emergency wards of Romania. The large - scale availability of this test and a high rate of litigations concerning the malpractice related to unfound heart attack can attract emergency physicians in routine testing for this marker, even at patients without clinical manifestations of the acute coronial syndrome. This practice leads to many false positive results and to the increase of care costs by hospitalization and to the useless testing of low risk patients ${ }^{4}$. The public perception can be very different from what the medical specialty literature records. The easy access to information and to the "marketing” of medicine can impose such perceptions which consider certain tests or treatments as infallible ones.
The theory of hazard can explain the phenomenon from a mechanical perspective, as well as an analogy with the physical phenomenon without taking into consideration important matters from social point of view as the cultural ones. It is obvious that whether of how much a series of safety procedures would be implement or how much the medicine science would evolve, a series of errors and negligence would exist just from the deep kind of humans who participate at the therapeutic process. Thus, the theory of hazard clarifies a basic level of the claimed incidents rate (real or less objective); it is important if we emphasize the problem of errors as probabilities existing permanently in the humans' lives. Practically, each physician tries to explain to his patient the opportunity of a patient in a balance of risks and benefits which, essentially, represent some probabilities, even though, they do not always take the form of some accurate figures. The acceptance at social level of the hazard can be different from one society to another; in the case of our society, in the individual speeches, reflected in the media or by other channels, we can find a series of expressions like: "that's how it was meant to be”, „this is what God wanted” or „he died on his feet". Each of them reflects a certain approach of passive acceptance of hazard, of rejection and submission against a divine will or a less explicit rejection, but accompanied by a rejection of fatal consequences of medical treatments. Two historical and cultural matters are, probably, important concerning the approach of hazard in the public consciousness of our society. The communism period with its ideological pressures and the Christian - Orthodox tradition which, even though in opposition, reject the hazard due to various reasons.

The medical malpractice can be understood having as central element the relationship between physician and patient which becomes a conflictual one, and an entire series of explanations can be obtained from a sociological perspective of the medical occupation and medical assistance. The starting point can be represented by the theory of Donald Black concerning the social control and also after some empirical findings performed after the analysis of malpractice litigations of the United States of America. The conceptualization starting from this theory presupposes to take into consideration some vertical, organizational and relational distances between the patient which is considered damaged and the provider of medical services. Starting from these reasons, a series of previsions can be obtained concerning the number, moment and method in which the claims for indemnities can be solved after a medical action considered defective. Such social 
and structural variables contribute to the explanation of some matters as they are: the global increase of paid indemnities level (at least in the American health system in the $70-90 \mathrm{~s}$ ), the persistence of the humans' tolerance as response methods against insults due to medical guiltiness, the higher vulnerability of patients from social categories with lower incomes, the higher litigious risk of surgical specialties in comparison with general medicine and psychiatry, the higher and disproportionate frequency of suing the physicians individually and not the hospitals and the high frequency of some decisions in the favour of patients when a decision is ruled in court against the situation of analysis in a professional forum ${ }^{5}$. The comeback on these theoretical reference points has an entire series of objectives: the supply of some additional and pertinent explanations taking into consideration the insufficient explanations which a theory of probability and hazard can bring, the verification of confirmation of these theoretical matters in time, respectively in another health system than the one by the analysis of which it has been enunciated. Last but not least, these have a theoretical usefulness in enunciating some new and, as much possible, more comprehensive perspectives or theories concerning the medical malpractice phenomenon.

The social control refers to all the actions which, on one hand define and, on the other hand, respond to a behaviour which is considered deviant. A deviant behaviour is one considered unwanted from moral point of view and not from intellectual or esthetical point of view ${ }^{6}$. The fundamental axiom of the social control theory affirms that the law and other varieties of conflict management depend on the various social or structural circumstances. Thus, the legal system which regulates the malpractice is different from one society to another even if the defining doctrinal elements are common. Five main dimensions of the social structure are identified: vertical, horizontal, cultural, organizational and normative ${ }^{7}$. The vertical dimension refers to the unequal distribution of richness. The horizontal dimension includes the degrees of intimacy and interdependency between humans, as well as their integration in the social life. The cultural dimension refers to the variation of customs, beliefs and knowledge. The organizational dimension concerns the differentiated capacities of collective action against a deviant behaviour. Eventually, the normative dimension is indicated by the spreading and type of the social control to which humans are subject. These dimensions and their component parts are different at conceptual level, but it can be corelated empirically. It can be said that it defines a multidimensional area in which the structural positions of individuals can see comparatively, meaning, their social status and social distances, some against the others. The relative positions of the participants within the therapeutic relationship (physician and his patient) define the social structure of a malpractice conflict case, and any other third party is not part of this structure ${ }^{8}$. The social structure explains the variation both in qualitative matters and quantitative matters of the social control. The qualitative variation of social control has a huge diversity by various actions in front of various courts, censorship, public comments, persuasion, gossip and even revolts. If we refer to our health system, it can be seen that the resolution of the conflict between the physician and patient can be done using a series of institutions, even if their competence is not identical: College of Physicians, Malpractice Cases Supervision Boards from the Authorities of Public Health, the Civil or criminal case courts; the public perception is severely influenced by the media or online channels. The style of social control refers to the way in which a deviant behaviour is defined and regulated. Four major styles are found: criminal, countervailing, consultative and therapeutic ${ }^{7}$. Each style represents a different approach depending on the type of deviant behaviour and offers adequate solutions and compliant with the specific provisions. If the damages fall into the criminal provisions (for example aggravated body injury), the consequences can be even a custodial measure for the incriminated physician. If we refer to the civil provisions which presuppose the repair of the caused damage, it can result the payment of an indemnity which covers both the material and moral damage. The criminal style tries to punish a perpetrator; the circumscription of the perpetrator in this category has, as basis, the severity of an offence which the criminal policy of the state punishes. The countervailing style tracks the return of damage if the repair in kind is not possible. The conciliation style tries to re-establish the peace in the relationship between parties and has, as basis, the functioning of the mediation boards or institutions which represent an alternative method, which is extrajudicial, for the resolution of conflict. We can talk about a therapeutic style by which they want to remedy or offer a "help" to those who manifest an unwanted conduct; examples can be found in our realities, like the decisions given by the College of Physicians by which the involved physicians are obliged to courses of professional training. In contrast to the style, the social control form 
refers to the mechanisms by which the applicants' complaints are expressed. Five basic forms exist: self-help, avoidance, tolerance, negotiation and resolution ${ }^{9}$. Selfhelp presupposes the use of some direct and aggressive means, practically the complaint is displayed by a direct approach of the person suspected to cause the damage and can be seen as a pressure form, even revenge. Both the avoidance and tolerance are „minimalist” forms of action from the persons who considers themselves as aggrieved $^{10}$. The difference between the two forms is that the avoidance presupposes the diminution of interaction and the tolerance presupposes the absence of any visible action. Negotiation involves both parties with the mutual purpose of calming their conflicts. The resolution is done only by the third party, external to the conflict and who can have various degrees of authority depending on how he/she is invested: we can include here various courts or mediation institutions ${ }^{11}$. The use of various styles and forms involve a large variety of activities and actions of humans, varying from unilateral control to multilateral control, from informal to formal, from direct confrontation to hidden confrontation, from nonviolent to violent. The combination of these styles and forms leads to different approaches in different cultures and systems.

In comparison with other styles of social control met in legal conflicts, the countervailing style which acts in the cases of malpractice is most probably to be invoked in ascending conflicts, when the abused one has a general low status than the deviant pretended party ${ }^{7}$. Other types and sources of social status can be discussed (integration degree, cultural capital) which can be potentially correlated with the countervailing style of social control. In a general analysis, the use of income to measure the social position on vertical, we can see that the patients tend to be localized inferiorly in comparison with their physicians. This matter has been often used in the studies of the United States of America where the income is a strong predictor concerning the use of medical care services; its importance seem to be lower in countries in which services with a strong social component are predominant, of which payment is an indirect one, after the fees applied directly to incomes. An example is represented by the British health system, which is predominantly public, by the NHS (National Health Service) network. The perspective of the higher status of physicians by the influence of organizational status can be an important factor; in comparison with patients, the physicians are part of collegial structures (College of Physicians) to which a series of professi- onal structures are added depending on specialty; the association of patients in organizations which try to defend a series of rights is still at the beginning (at least in Romania). This type of organizational affiliation on the civil society principles exists to the same extent on both sides. The quantification of the level of organizational status can be done by the evaluation of number of group relationships of the individual; without taking into discussion the intensity of these relationships is easy to see that the number of relationships in the case of physicians is net higher. The professional and regulation organizations of the sanitary department can have a significant influence in the institutional legislative and regulation process, contributing to the difference of status. In many situations, perceptions are contoured concerning the one-sided attitude of such organizations regarding the medical errors or at least evasive attitudes, which do not constitute themselves in real „warning signals" in the case in which it would have been necessary or it has been intensely mediated.

The vertical and organizational superiority of the potential "perpetrator" inhibits the use of law by the damaged ones; in other words, the lower social status of the aggravated party promotes tolerance against the deviant behaviour. The toleration as type of behaviour from the patient represents a lack of reaction, the failure to submit an indemnity request in the presence of an injury as consequence of a negligent or erroneous treatment ${ }^{12}$. Taking into consideration these superiority tendencies of physicians on vertical and organizational dimension in comparison with their patients, studies exist which confirm the discrepancies between the number of acknowledged lesions as result of a negligence and the number of indemnity requests. This report varies, depending on research, from 8:1 to $15: 1^{13,14}$. Despite the increase of the rate of indemnity requests from the last four decades, the tolerance seems to be the majority answer to potential litigious events. These studies do no approach specially if the avoidance is used in addition to the toleration, and the mentioned investigation has used independent experts who have analyzed retrospectively the records from hospitals. The inference which can be seen in the cases of malpractice is that the malpractice errors increases rarely up to the level of "dispute", in the regard of a bilateral conflict, an argument which involves an accusation from a party and the negation from the second party. If an accusation of malpractice is submitted, it is done informally, to the family and friends. The higher status of the perpetrator stimulates the "gossips", one type of trial in 
absentia and less a direct confrontation. The process is similar in time, only the expression media has changed by the evolution of the new technologies: we have blogs, groups of social networks as "discussion” media for various potential litigious medical cases. Even the online news is accompanied by reactions, shares and comments on the internet website of newspapers or media agencies. The complaints related to malpractice tend to be treated with the techniques of „moral minimalism" ${ }^{10}$ : toleration, avoidance and gossip. A complaint of malpractice is classified as a tolerated one to the extent in which the presupposed perpetrator is never conscious about the fact that it is acknowledged in the patient's mind.

\section{MATERIALS AND METHODS}

For this research, we have used the interrogation of the Courts Portal of Romania. The Portal of Courts of Romania allows the access of Romanian citizens and of the other Member States of the European Union to information referring the judged cases or the pending cases in front of the Romanian courts. A series of information about the courts of Romania can be found here. The portal offers a large quantity of information, the update is done daily and represents practically an official, formal image of litigious situations. In addition to data with administrative feature of courts (presentation and organization of court, authority awarded to the court with the possibility of searching localities, streets, numbers and postcodes given to a court, the calendar of meetings and lists of meetings), information about the pending cases, the search of file on number, the involved party and procedural object can be obtained. The latter matter is of interest in this section of research. The jurisprudence analysis concerning the medical malpractice, published on portal, can bring important information and is the subject of a separate analysis. The portal can be accessed at the address: http://portal. just.ro/SitePages/despre.aspx. The database which we will use for the analysis of a series of information has been obtained by the interrogation of the Courts Portal on two key words: „malpractice” and „physician”. The portal has generated a number of 376 results beginning with 27.11.2007 (this is the moment when this official system of electronic data management has begun) and until 01.04.2018 (when the interrogation has been done). After eliminating the doubles and the files concerning the studied theme, a number of 331 cases have been kept, for which the analysis of data is done. The statistical correlations have been done using statistical functions of Excel MS Office program. The social economic indicators have been extracted using the portal of the National Statistics Institute at the address: http://statistici.insse.ro:8077/tempo-online/\#/pages/ tables/insse-table.

\section{RESULTS AND DISCUSSIONS}

The first part of the analysis is represented by a descriptive analysis, concerning the number of cases registered at courts as litigious risk during the occupation of physician. The first apprehended matter is that the number of trials which have as basis a medical case considered (at least at the moment of submitting the action in $\mathrm{co}^{-}$ urt) defective or injuring is permanently increasing.

The number of trials registered during 2007-2018 is given in Table 1; for 2007 and 2018, an extrapolation has been done at the level of a calendar year with the purpose of performing a preliminary assessment of the tendency concerning the number of registered files. The evolution of the global number of trials registered at the courts of Romania (whether of the institution rank) is given in Figure 1.

Another preliminary analysis is represented by the observation of the type of court at which a file has been registered at the moment of the portal interrogation. The distribution of files on Court of First Instance (District Courts), Tribunals (County Courts) and higher courts (Court of Appeal) can be seen in Tables 2, 3 and 4 .

Table 1. Evolution of the number of files in the Romanian courts. Source: www.portal.just.ro (NB: The data for 2007 and 2018 are extrapolated to the level of a calendar year)

\begin{tabular}{|l|c|}
\hline \hline Year & Number of files registered at the court level \\
\hline $2007 *$ & 7 \\
\hline 2008 & 8 \\
\hline 2009 & 5 \\
\hline 2010 & 12 \\
\hline 2011 & 19 \\
\hline 2012 & 13 \\
\hline 2013 & 35 \\
\hline 2014 & 46 \\
\hline 2015 & 40 \\
\hline 2016 & 58 \\
\hline 2017 & 65 \\
\hline $2018 *$ & 115 \\
\hline
\end{tabular}


Evolutia numarului de procese

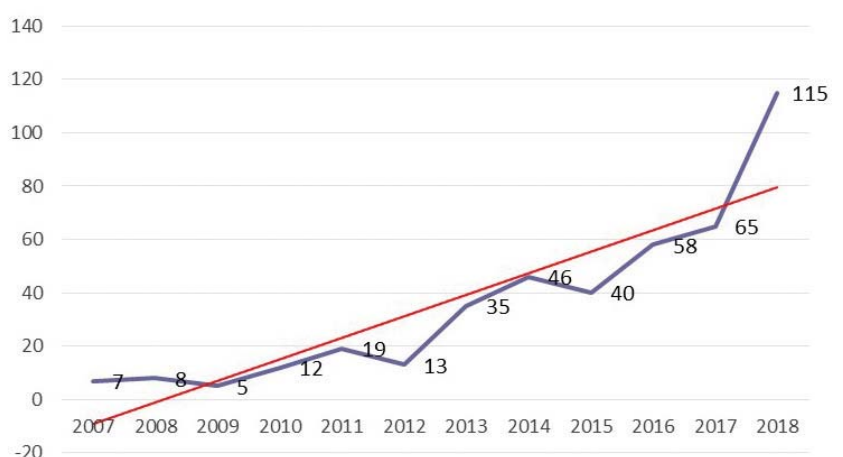

Figure 1. Increasing trend of the number of trials registered in the period 2007-2018 Source: www.portal.just.ro.

\section{Geographical distribution}

The geographical distribution is not an uniform one, justifying a special attention on this matter as well as a detailed analysis starting from the theoretical reference points mentioned above. Subsequent comparison and correlations are necessary to clarify the litigious phenomenon related to malpractice. In this regard, we propose the use of some social - economic indicators and of some which describe globally the autochthonous health system available in the INS references (National Statistics Institute) and online at the address: http:// statistici.insse.ro:8077/tempo-online/\#/pages/tables/ insse-table. Such indicators are found in a series of official reports as the "Activity of sanitary units" which has an annual frequency (http://www.insse.ro/cms/files/ catalog/Catalogul-publicatiilor_INS_2018.pdf). The evaluation of the number of processes in absolute numbers does not bring relevant information and references must be done taking into consideration other indicators too. The importance of such systemic indicators has led to their use by other bodies as the Romanian College of Physicians; the activity reports of the $\mathrm{Hi}^{-}$ gher Discipline Board mention such numbers (https:// www.cmr.ro/new/index.php/2017/03/raportul-de-activitate-al-comisiei-superioare-de-disciplina/).

Regarding from this perspective, the premises exist to discover that the real rate of malpractice situations

Table 2. Distribution of the number of files registered at Courts of Firs Instance during the period 2007-2018 Source: www. portal.just.ro

\begin{tabular}{|c|c|c|c|}
\hline Court of First Instance & No & Court of First Instance & No \\
\hline Arad & 7 & Petroșani & 1 \\
\hline Bacău & 1 & Piatra-Neamț & 7 \\
\hline Baia Mare & 1 & Pitești & 11 \\
\hline Bârlad & 2 & Reșița & 1 \\
\hline Bistrița & 2 & Satu Mare & 1 \\
\hline Botoșani & 3 & Bucharest District 1 & 31 \\
\hline Brăila & 3 & Bucharest District 2 & 17 \\
\hline Brașov & 4 & Bucharest District 3 & 3 \\
\hline Buzău & 2 & Bucharest District 4 & 3 \\
\hline Calafat & 2 & Bucharest District 5 & 3 \\
\hline Călărași & 1 & Bucharest District 6 & 1 \\
\hline Cluj-Napoca & 10 & Slatina & 1 \\
\hline Constanța & 9 & Suceava & 5 \\
\hline Craiova & 11 & Târgu-Jiu & 2 \\
\hline Curtea de Argeș & 1 & Târgu-Mureș & 2 \\
\hline Făget & 1 & Târgu-Neamț & 1 \\
\hline Focșani & 3 & Târgu-Secuiesc & 1 \\
\hline Galați & 3 & Tecuci & 1 \\
\hline Huși & 1 & Timișoara & 15 \\
\hline Iași & 8 & Topoloveni & 2 \\
\hline Lehliu-Gară & 1 & Tulcea & 1 \\
\hline Moinești & 2 & Zalău & 1 \\
\hline Orăștie & 2 & \multirow[t]{2}{*}{ Total Number } & \multirow[t]{2}{*}{193} \\
\hline Pașcani & 2 & & \\
\hline
\end{tabular}


Radu Mihai DUMITRESCU

Table 3. Distribution of the number of files registered at Tribunals during the period 2007-2018 Source: www.portal.just.ro

\begin{tabular}{|l|c|l|c|}
\hline \hline Tribunal & No & Tribunal & No \\
\hline Arad & 4 & Dolj & 4 \\
\hline Argeș & 6 & Galați & 2 \\
\hline Bacău & 5 & Gorj & 2 \\
\hline Bistrița Năsăud & 1 & Hunedoara & 1 \\
\hline Botoșani & 2 & lași & 8 \\
\hline Brăila & 3 & Mureș & 2 \\
\hline BUCUREȘTI & 33 & Neamț & 1 \\
\hline Buzău & 3 & Satu Mare & 1 \\
\hline Călărași & 2 & Timiș & 1 \\
\hline Caraș-Severin & 1 & Tulcea & 3 \\
\hline Cluj & 4 & Vaslui & 1 \\
\hline Constanța & 2 & Total Number & 1 \\
\hline
\end{tabular}

Table 4. Distribution of the number of files registered at Courts of Appeal during the period 2007-2018 Source: www.portal. just.ro

\begin{tabular}{|l|c|l|c|}
\hline Court of Appeal & No & Court of Appeal & No \\
\hline Alba Iulia & 1 & lași & 2 \\
\hline Bacău & 2 & Pitești & 1 \\
\hline Brașov & 1 & Ploiești & 1 \\
\hline BUCUREȘTI & 10 & Târgu-Mureș & 2 \\
\hline Cluj & 2 & Timișoara & 7 \\
\hline Constanța & 2 & Total Number & $\mathbf{3 6}$ \\
\hline Craiova & 5 & & \\
\hline
\end{tabular}

is one which embeds within the limits of other health systems considered performing. The reference to the performance of system can change the perspective against the eventual tendency of „disfavour" manifested publicly by various occasions, many times in the news from the media. In such a situation, the explanations will be searched in a sociological and public communication analysis. The Romanian College of Physicians considers that, at global level, the medical activity is really prodigious for 2016 - over 180 million supplied medical services by almost 60.000 physicians. 8.5 services per inhabitant and 3000 services / physician exist. Only the one day hospitalization and the permanent ones are 7 million $^{16}$. The same report mentions that only $14.7 \%$ of the physicians have been sanctioned out of 171 claimed for disciplinary deviations and incompliant medical activity in performing medical services. An important matter is the fact that the complaints in front of the college represent only one of the possibilities which the patients have and concern in legal reality the analysis of cases from the perspective of professional deontology and conduct; the overlap with the presentation of the same case in justice is only a partial and uneven one. A separate analysis from the perspective of disciplinary liability is found in a separate research published previously in this journal. The presentation of these figures, for one calendar year, has the role of justifying the need of a deeper research, from systemic perspective as it can be seen further.

By the use of preliminary data from the built database, an important series of other data can be obtained, as the procedural duration, the procedural stage and the evolution of such types of litigation on court categories, the number of involved parties. The content analysis of the ruled solutions can bring data concerning the value of indemnities and more subtle data as defended social values, legal doctrine taken into consideration, aggravating elements or the way in which the personal data and the special data (medical) are processed.

\section{Distribution of files on territorial - administrative units (Counties) and on types of courts}

An aggregation of files of courts in university centers of training in medicine can be seen in Figures 2, 3 and 4. On the first place we find the capital city followed 


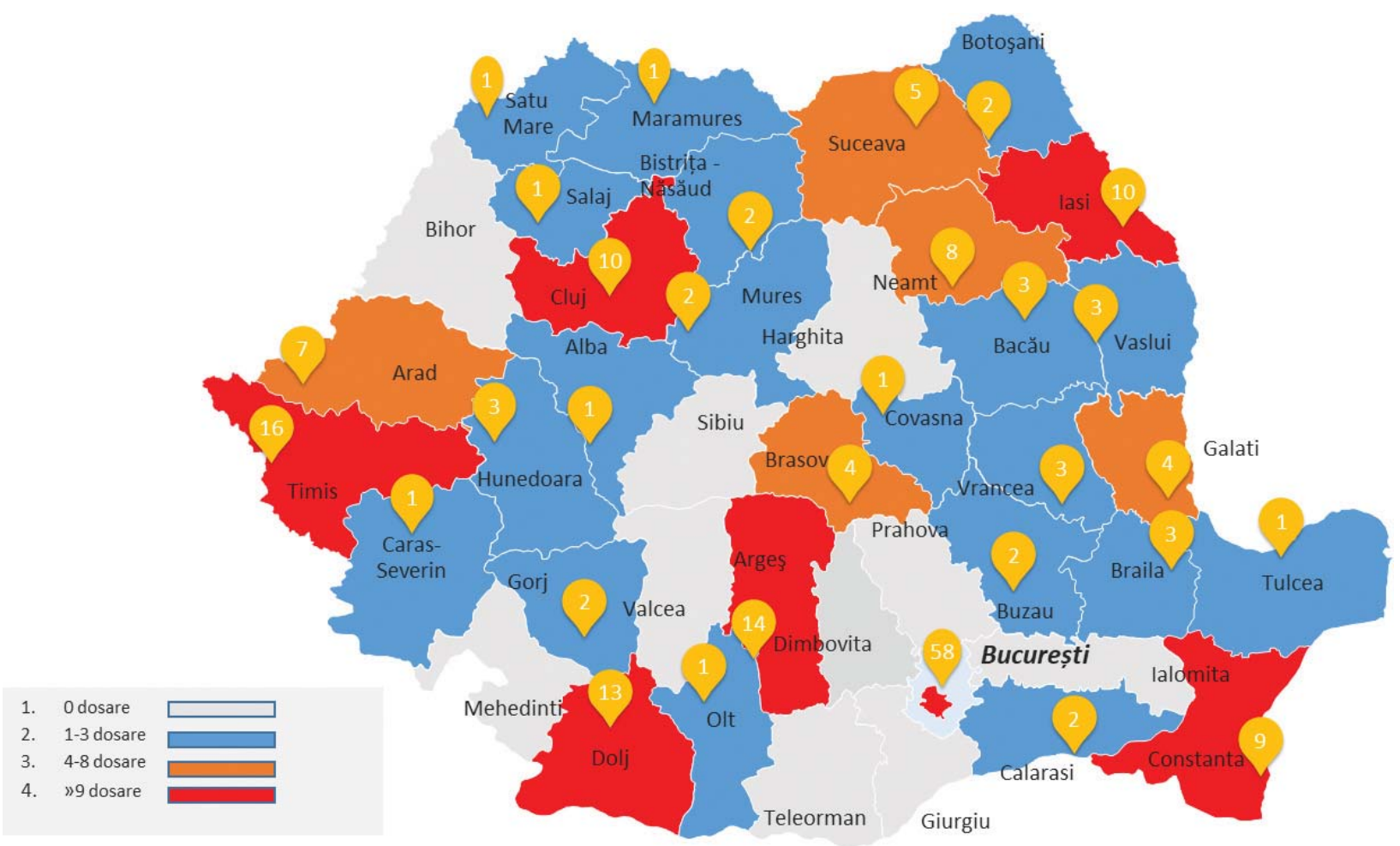

Figure 2. Distribution by territorial-administrative units (counties) of the files registered at The Courts of First Instance (Judges) during the period 2007-2018 Source: www.portal.just.ro.

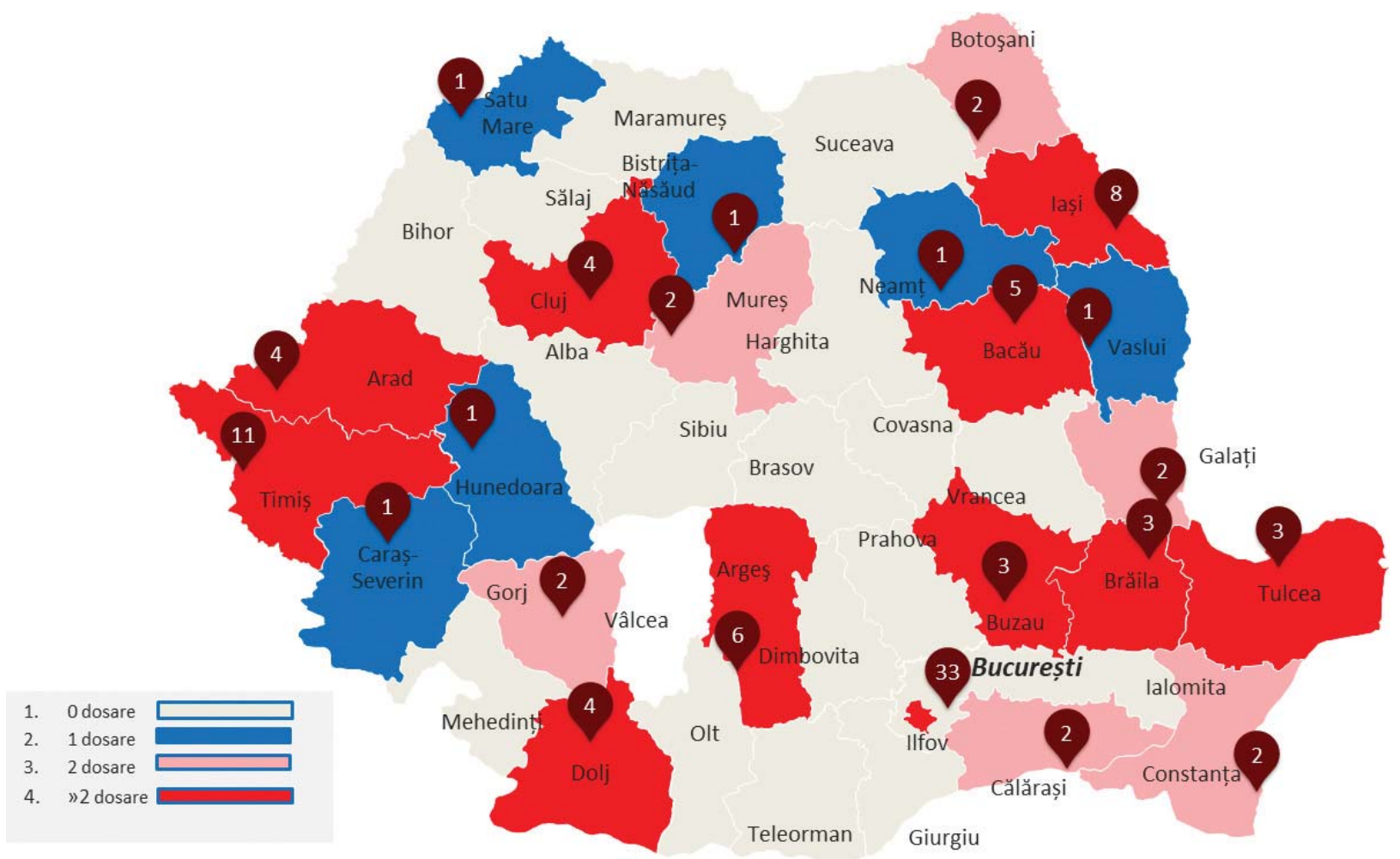

Figure 3. Distribution by territorial-administrative units (counties) of the files registered with the courts (Tribunals) during the period 20072018 Source: www.portal.just.ro. 


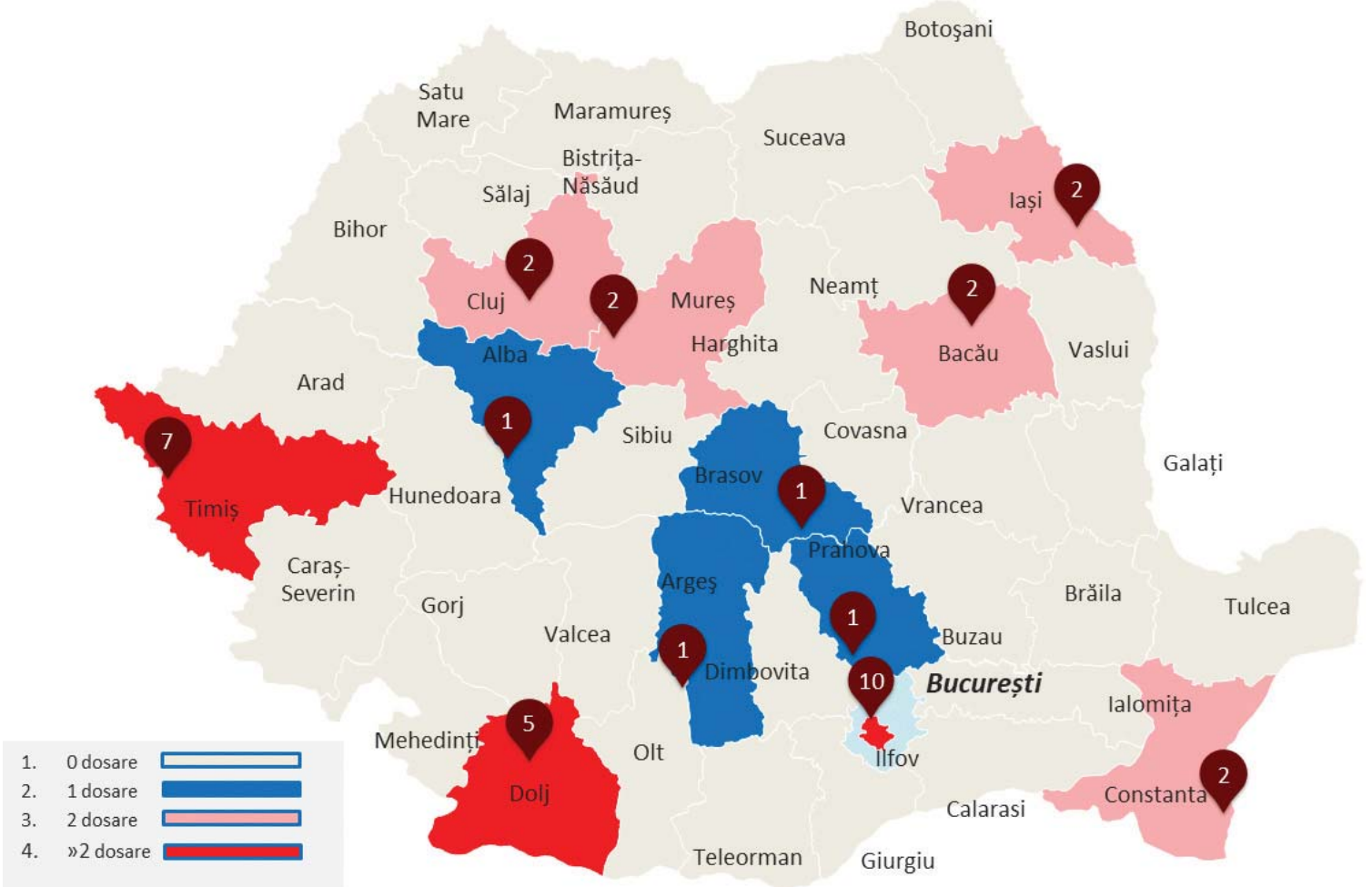

Figure 4. Distribution by territorial-administrative units (counties) of the files registered with the courts (Courts of Appeal) during the period 2007-2018 Source: www.portal.just.ro.

by the Timisoara, Craiova, Iasi, Cluj and Constanta centers. An interesting matter is the large number of filed in Arges and Tulcea Counties; at least for the latter the lack of staff and the dysfunctionalities of the sanitary system are much known. This distribution of files reflects, most probably, the volume of activities in these centers, as well as the complexity of treated cases. Most probably, we have in the system a tendency to transfer cases to the university centers which can treat more difficult cases. The litigious risk related to the medical practice is higher; it is possible that the absolute risk does not suffer increases if the volume of treated patients is calculated. A similar matter has been discussed in the case of assessing the risk of being subject to a procedure of disciplinary liability in front of college boards. Such a distribution of cases can confirm a theory of hazard, but the progressive increase of the global number of files cannot be explained convincingly by such a theory. This matter, together with the uneven distribution at geographic level, has led to the need of investigating if sociological theories are confirmed which guide towards correlations with other social and economic features of the health system. Such an analysis can be found in the following sections.

\section{Litigious duration - time necessary to rule a solution in court}

From the analysis of the preliminary data, the time necessary to obtain a decision in court could be calculated, without performing an analysis of confirmation or not of the malpractice existence. This matter becomes more important as the public perception heads towards critical appreciations concerning the duration of trials, whether of the field in which they take place. Analyzing the 316 (out of the total of 331 introduced in the database) for which a solution posted on portal exists; an average of the days necessary for the enunciation of a solution by the court could be calculated. The calculated average is 296.18 days. It can be seen that trials for which the number of days is smaller from 0 to 14 exist and which represent, most probably, cases in which procedure vices have existed or in which administrative solutions have been ruled.

For a general image of the duration of these trials, we have analyzed their number depending on the number of days necessary to rule a solution. This matter is mentioned in Table 5. 4 files exist in which the resolution has been done after more than 2000 days (2131, 2142, 2693 and, respectively, 2816 days). To be able to 
Table 5. The number of files depending on the duration of the settlement

\begin{tabular}{|l|c|}
\hline Duration of settlement in days & Number of files \\
\hline $200-299$ & 38 \\
\hline $300-399$ & 19 \\
\hline $400-499$ & 21 \\
\hline $500-599$ & 9 \\
\hline $600-699$ & 12 \\
\hline $700-799$ & 9 \\
\hline $800-899$ & 5 \\
\hline $900-999$ & 4 \\
\hline $1000-1999$ & 12 \\
\hline "2000 & 4 \\
\hline
\end{tabular}

identify these solutions with a longer duration of resolution, the number of file registered in the portal is: 42687/212/2010, 34242/211/2011, 42647/212/2010 respectively $9142 / 302 / 2010$. In this codification, the second number represents the code of court, and the third one represents the file registration year.

If we remove 51 trials for which the solution has been ruled within maximum 30 days, the average will be calculated for 265 files. The files removed from this assessment, have been considered strictly procedural. The average of number of days for the resolution of such cases is 350.68 days. In other words, it is less probable that a medical litigious situation is solved in less than one calendar year; this matter has a negative impact for the petitioner of whom objective is to repair the damage and use of indemnities to restore the health condition and for the involved physicians.

To evaluate if the duration for the resolution of such cases is higher than the averages from global level of the justice system, we have analyzed the report concerning the justice status in 2016 drafted and published on the official website of the Higher Council of Magistracy. In the case of district courts, the total average duration for resolution (in days) has been: 117.6 days for civil cases, 178 days in the cases of litigations with professionals, 195.8 days for cases with minors and family and 93.4 days for criminal cases. In the cases of county courts, on the merits, these averages are 275, 163, 81 and respectively 54 days ${ }^{17}$. Solid hints exist which certify that the procedural duration in the cases of malpractice exceed the averages of the judicial system. The cases which lead to a delay of resolution of these files are multiple and can represent different matters to be investigated.

The excessive duration of judicial procedures has represented many times a media subject, and also of convictions of the Romanian State by the International
Courts, as well as CEDO (European Court for Human Rights). In the online media, an entire series of such data can be found. The nongovernmental organizations and associations are careful and claim repeatedly these matters. „According to CEDO, a systemic problem concerning the duration of judicial procedures exists in Romania. The court indicated that until now it has ruled concerning almost 200 cases related to the duration of judicial procedures and other almost 500 cases are pending concerning the same problem, all against Romania"18. The legal literature registers various causes of this matter. The unjustified delay of solving files can be the cause of experts, witnesses (in absentia), lawyers (the absence of the defendant's defender in the cases in which the legal assistance is compulsory determines the courts to submit repeatedly hearings), the court (for example, the failure to apply, by the court, of the sanctions imposed by the failure to observe the obligations established by the court) or due to other authorities $^{19}$. It is very probably that in the case of files with malpractice litigations, the delays have as basis the difficulty to obtain forensic reports and the functioning method of the Institution which drafts these reports (Forensic Institutes and Laboratories).

\section{The number of involved litigious parties}

From the initial analysis of data, the average number of parties involved in such a process can be calculated. This figure orientates on the number of humans involved in such a judicial approach which embeds an entire series of undesirable effects, at least of economic and emotional order. This evaluation has been used in a different section of the paper for the appreciation of the malpractice phenomenon as a potential social problem. The average number of involved parties is 4.14 , but this number is obviously an under-evaluated one, taking into consideration the series of administrative files, appeal of an action, in which we have only 2 parties (in these case, one of the parties is represented by the Authority of Public Health of a County or by the afferent Malpractice Cases Monitoring Board). Removing these files, we obtain an average which is close to reality and which is situated around the value of 10 . This matter guides us on the severe social impact which such a process can have. There are files in which 27 parties are found (example file no. 10712/215/2017). This matter seems a normal one, taking into consideration that in many litigious medical cases we talk about the involved therapeutic teams, and the autochthonous jurisprudence heads towards ,joint tort civil liability”. 
The identification of parties, similar with the identification of courts, describes the distribution of files on administrative - territorial units (counties) as it has been presented previously.

\section{Secondary analysis - correlations with social and systemic indicators}

Starting from the theoretical reasons described in the theory of social control involved in the medical malpractice phenomenon (Donald Black) (6), we have tested the existence of some correlations between the number of files identified in the portal of courts and a series of social indicators extracted after the interrogation of the portal of National Statistics Institute at the address http://statistici.insse.ro:8077/tempo-online/\#/ pages/tables/insse-table. The distribution of number of files, as well as the value of indicators has been kept on territorial - administrative areas (counties), and the secondary data (averages, rates) have been kept for the a range of time similar to that of files of justice (2007 - 2018); for certain indicators, no data have been available for the entire range of time. The indicators used in the analysis, as well as the range of time are found in the attached table. Using the statistical functions of the Excel MS Office program, the Pearson Correlation Coefficient has been calculated and interpreted according to the rules of Colton (value of correlation coefficient between $0.3-0.5=$ reduced intensity correlation, between $0.5-0.7=$ medium intensity correlation, and values higher than 0.7 certify a strong intensity between the two determinants ${ }^{20}$. The calculated value of the correlation coefficients is found in Table 6 . To reduce

\begin{tabular}{|c|c|c|c|c|c|}
\hline & Social Indicator & Available data used & Way of Ussage & $\begin{array}{l}\text { Code } \\
\text { according to } \\
\text { National } \\
\text { Institute of } \\
\text { Statistics }\end{array}$ & $\begin{array}{l}\text { The value } \\
\text { of the } \\
\text { Correlation } \\
\text { Coefficient }\end{array}$ \\
\hline 1 & Resident population & Average 2012-2018 & Calculation rate & POP105A & - \\
\hline 2 & Civil active population & Average 2007-2017 & Rate - Correlation & FOM102 & 0,497701 \\
\hline 3 & Male civilian active population & Average $2007-2017$ & Rate - Correlation & FOM102A & 0,409389 \\
\hline 4 & Female civilian active population & Average 2007-2017 & Rate - Correlation & FOM102A & 0,554863 \\
\hline 5 & Registered unemployed & Average 2007-2018 & Rate - Correlation & SOM101A & $-0,304634$ \\
\hline 6 & Doctors (excluding dentists) & Average 2007-2017 & Rate - Correlation & SAN104A & 0,709568 \\
\hline 7 & Other types of personnel with higher education & Average 2015-2017 & Rate - Correlation & SAN104A & 0,473984 \\
\hline 8 & Nurses with higher education & Average 2015-2017 & Rate - Correlation & SAN104A & 0,412615 \\
\hline 9 & Sanitary personnel with high school training & Average $2007-2017$ & Rate - Correlation & SAN104A & 0,581708 \\
\hline 10 & Nurses & Average 2015-2017 & Rate - Correlation & SAN104A & 0,595571 \\
\hline 11 & Midwives & Average $2007-2017$ & Rate - Correlation & SAN104A & 0,192202 \\
\hline 12 & Hospital beds & Average 2007-2017 & Rate - Correlation & SAN102A & 0,592970 \\
\hline 13 & Gynecology and obstetric beds & Average2007-2017 & Rate - Correlation & SAN102A & 0,399913 \\
\hline 14 & Number of live births & Average 2007-2017 & Rate - Correlation & POP201D & 0,067780 \\
\hline 15 & Mortality rate born dead & Average 2007-2017 & Rate - Correlation & POP204C & $-0,265880$ \\
\hline 16 & Dead by tumors & Average 2007-2017 & Rate - Correlation & POP2061 & 0,205551 \\
\hline 17 & Death through diseases of the central nervous system & Average 2007-2017 & Rate - Correlation & POP206I & 0,126977 \\
\hline 18 & Death by circulatory system diseases & Average 2007-2017 & Rate - Correlation & POP206I & $-0,242730$ \\
\hline 19 & Death from ischemic coronary heart disease & Average 2007-2017 & Rate - Correlation & POP206I & $-0,193002$ \\
\hline 20 & Death from cerebrovascular disease & Average 2007-2017 & Rate - Correlation & POP2061 & $-0,111312$ \\
\hline 21 & Death by respiratory diseases & Average 2007-2017 & Rate - Correlation & POP206I & $-0,105527$ \\
\hline 22 & Deceased during pregnancy or leisure & Average 2007-2017 & Number - correlation & POP2061 & 0,495568 \\
\hline 23 & Work accidents & Average 2007-2017 & Number - correlation & ACC101B & 0,907039 \\
\hline 24 & Temporary incapacity for work & Average 2007-2017 & Number - correlation & ACC101A & 0,905833 \\
\hline 25 & Deadly work accidents & Average 2007-2017 & Number - correlation & ACC101B & 0,893228 \\
\hline 26 & Deadly work accidents in collective accidents & Average 2007-2017 & Number - correlation & ACC101B & 0,566047 \\
\hline 27 & Dead in collective accidents & Average 2007-2017 & Number - correlation & ACC101B & 0,203029 \\
\hline 28 & Rate of accidents at work (promile) & Average 2007-2017 & Number - correlation & ACC101B & 0,086377 \\
\hline
\end{tabular}


the population effect, the rates for various coefficients has been calculated depending on the resident population on each territorial - administrative unit (County).

A positive correlation of medium intensity with the number of active population can be seen, suggesting a correlation of the medical malpractice phenomenon with the size of the population in a geographical area; this matter is compliant with the probabilistic theory described starting from the theory of Bayes. However, a strong correlation is identified in relation with the number of physicians who work in an area (0.709568). In comparison with the other categories of staff which register a medium correlation (nurses, other types of medical staff), in the case of midwives a weak correlation can be seen. These matters suggest a series of particular matters; in the perception of population, the physician has bigger role in the complex of medical treatment and an increased responsibility is awarded to him. Even though obstetrics is on the first place for the litigious risk (as it results from literature, from the analysis of disciplinary actions (Dumitrescu, 2019) and also from media news) a weak correlation can be seen with the number of obstetrics beds in the health system (0.399913) and with the number of midwives (0.192202). The number of midwives needs different analysis taking into consideration the evolution in time of this professional category, their limited number in our medical system, as well the restrictions concerning the regulation of the occupation regarding the role and responsibilities. The responsibility of the obstetrician, in comparison with the one of the midwife is a superior one both by the legal autochthonous provisions and by the way in which the population chooses to request specific services; even though the attitude of women concerning the birth have evolved in time from an anthropological mechanism of birth of technocrat type to a holistic one, it is very probably that the weight continues to be a reduced one at global level. The stronger correlation relationship concerning the hospital beds (as global number) in comparison with the specific ones for obstetrics seems to confirm the important value of the probabilistic factor described by the theorem of Bayes. But, this theory cannot predict the entire litigious phenomenon related to malpractice which has a series of determinants: cultural, economic and behavioural.

From theoretical point of view, it is predicted that the number of malpractice processes is dependent on the social and economic development which is reflected in the health condition of the population from an area. The test of correlation with the number of deceased patients has been tried after some various categories of pathologies (cardiovascular, respiratory, of the central nervous system, tumors, etc.). Some of the correlations have been weak (positive or negative), without large significance. It is possible that no significant differences exist between the areas of the country depending on the fact that these indicators or their relationships with the economic level of the area are not strong. The same matter is identified in the case of the number of deceased new-borns or the number of live births. It remains a strong enough correlation with the deaths registered during pregnancy and confinement (0.495568) confirming once again the litigious risk for this category.

Strong correlations are registered in the case of number of work accidents (0.907039), the number of deaths by work accidents $(0.893228)$ or the number of humans which register temporary incapacity to work (0.905833). The explanation of this matter needs additional investigations, similarities being possible concerning the procedural approach at system level of the two types of incidents and the social perception. The effect of population is a very important one, observing this from the fact that a significant correlation exists when global data of work accidents are compared (similar to the way in which the cases of malpractice are reported in justice) and not the calculation of correlation is reported to rates of work accidents.

\section{CONCLUSIONS}

The number of malpractice files registered at the courts of Romania has increased permanently during 2007 2018; the increase rate is difficult to explain only by a theory of hazard, such that the correlations started from sociological theoretic reasons prove to be useful. The geographical distribution of the number of files is not an uniform one, but an aggregation at the level of the university centers can be seen (in order Bucharest, Timisoara, Craiova and Iasi). A special matter is the big disproportionate number of files from Arges and Tulcea Counties which can be related to various dysfunctionalities of the sanitary system from this area (like the coverage with specialty staff). The aggregation of the number of files in the case of university centers can be due to the functioning method of the health system which presupposes a pyramidal, higher guidance of the difficult cases, as well as of the bigger number of physicians and hospital beds in these centers. The 
tests of statistical significance certify a significant difference between the geographical areas which also represent areas of economic development.

The duration of time necessary to obtain a solution in court is of almost 350 days, justifying the public perception concerning the deferral of legal procedures. The litigious duration is shorter in the cases with a strong administrative content while in the civil cases can be solved during the years; the official reports of the justice system confirm the bigger duration of time of these categories of processes.

The number of litigious parties is around 10 confirming the functioning method of the current medicine (in a therapeutic team and less in an individual practice) and the autochthonous jurisprudence (joint tort civil liability). The social impact becomes a sever one both for the patients and for the professional body.

The distribution of number of files is correlated strongly positive with the number of physicians (0.709568) and weakly with other categories of staff. In the case of midwives, the correlation is the weakest one (0.192202), even though the litigious risk for obstetrics is the highest. For our health system is most probably to have a higher social distance of midwives against the physicians, due to particular reasons (cultural and functional). The physician is the center of the therapeutic relationship and embeds the highest quantity of liability. The quantity of law which is applied to him in the case of an erroneous or negligent treatment is higher even if he acts in a therapeutic team.

\section{References}

1. Astărăstoae V. Experiența malpraxislui medical între previzibil și hazard. www.activenews.ro [Internet]. 2017 Oct 6; Available from: https://www.activenews.ro/stiri-sanatate/Experientamalpraxislui-medical-intre-previzibil-si-hazard-146579\%0D

2. Reason J. Human error: models and management. Br Med J [Internet]. 2000;320(7237):768-70. Available from: https://www. ncbi.nlm.nih.gov/pmc/articles/PMC1117770/

3. Zamfir C. Justitia romaneasca prinde viteza in procesele civile si comerciale (raport UE). www.startupcafe.ro [Internet]. 2016 Apr 12; Available from: https://www.startupcafe.ro/stiri-taxe20931784-grafice-justitia-romaneasca-prinde-viteza-procesele-civile-comerciale-raport.htm\%0D

4. Riaz H, Krasuski R. Best Practice Advisories Should Not Replace Good Clinical Acumen. Am J Med [Internet]. 2017;130(3):2456. Available from: https://www.amjmed.com/article/S00029343(16)30922-6/fulltext

5. Mullis J. Medical Malpractice, Social Structure, and Social Control. Sociol Forum. 1995;10(1):135-63.

6. Black D. Social control as a dependent variable. In: Black D, editor. Toward a General Theory of Social Control. New York: Academic Press; 1984. p. 1-36.
The correlations with the method in which the distribution of number of patients with different pathologies varies, are weak, not being, probably, strong correlated with the social and economic development of geographical areas. It remains a strong enough correlation with the deaths registered during pregnancy and confinement $(0.495568)$ confirming once again the litigious risk for this category.

Strong correlations are registered in the case of number of work accidents (0.907039), the number of deaths by work accidents $(0.893228)$ or the number of people who register temporary incapacity to work (0.905833). The explanation of this matter needs additional investigations, similarities being possible concerning the procedural approach at system level of the two types of incidents and concerning the social perception.

The theoretical reference points identified in the literature explain partially the distribution of the medical malpractice phenomenon, subsequent systematic studies being necessary to define a current theory adapted to the sanitary system of Romania.

Compliance with ethics requirements: The authors declare no conflict of interest regarding this article. The authors declare that all the procedures and experiments of this study respect the ethical standards in the Helsinki Declaration of 1975, as revised in 2008(5), as well as the national law. Informed consent was obtained from all the patients included in the study.

7. Black D. The behavior of law. Special Ed. Wagon Line: Emerald Group Publishing Limited; 2010.

8. Black D. Social Justice. Revised Ed. New York: Oxford Univeristy Press; 1993.

9. Black D. The elementary forms of conflict management. In: New directions in the Study of Justice, Law, and Social Control. New York: Arizona State University - Plenum Press; 1990. p. 43-69.

10. Baumgartner MP. The Moral Order of a Suburb. New York: Oxford Univeristy Press; 1988.

11. Black D, Baumgartner MP. Toward a theory of the third party. In Boyum KO, Mather L, editors. Empirical Theories about Courts. New York: Longman; 1983. p. 84-114.

12. Meyers AR. "Lumping it" $»$ : The hidden denominator of the medical malpractice crisis." Am J Public Health. 1987;(77):1544-8.

13. Danzon PM. Medical Malpractice: Theory, Evidence, and Public Policy. Cambrindge: Harvard University Press; 1985.

14. Harvard Medical Practice Study. Patients, Doctors, and Lawyers: Medical Injury, Malpractice Litigation, and Patient Compensation. Cambrindge; 1990.

15. Black D. Sociological Justice. New York: Oxford Univeristy PreSS; 1989. 
16. Colegiul Medicilor din Romania. Raportul de activitate al Comisiei Superioare de Disciplina pe anul 2016 [Internet]. Bucuresti; 2017. Available from: https://www.cmr.ro/new/index. php/2017/03/raportul-de-activitate-al-comisiei-superioarede-disciplina/

17. Consiliul Superior al Magistraturii. Raport privind starea justiției pe anul 2016 [Internet]. București; 2017. Available from: http:// old.csm1909.ro/csm/linkuri/10_05_2017_88065_ro.docx
18. Andreescu MN. CEDO sanctionează România pentru durata prea mare a proceselor. www.apador.org [Internet]. 2013 Nov 27; Available from: http://www.apador.org/cedo-sancioneazromania-pentru-durata-prea-mare-a-proceselor-2/

19. Gâlea RE. Studiu de identificare a principalelor surse ale duratei excesive a procedurilor în sistemul judiciar românesc. Rev Transilv Științe Adm [Internet]. 2011;2(29):57-75. Available from: http://rtsa.ro/rtsa/index.php/rtsa/article/viewFile/53/49

20. Colton T. Statistics in Medicine. New York: Little Brown Book Group; 1974. 56 p. 
